\title{
IBM KELOMPOK TANI TANAMAN PANGAN DAN SAYURAN DI KELURAHAN KOLHUA
}

\author{
Nova Deviyanti Lussy"1, Micha S. Ratu Rihi ${ }^{* 2}$ \\ \#1Jurusan Tanaman Pangan dan Hortikultura, Politeknik Pertanian Negeri Kupang \\ Jalan Prof. Dr. Herman Yohanis, Kelurahan Lasiana Kota Kupang \\ 1email.novadeviyanti1977@gmail.com \\ ${ }^{*}$ Jurusan Tanaman Pangan dan Hortikultura, Politeknik Pertanian Negeri Kupang \\ Jalan Prof. Dr. Herman Yohanis, Kelurahan Lasiana Kota Kupang \\ 2email. raturihimicha@yahoo.com
}

\begin{abstract}
ABSTRAK
Kelompok Tani Dael Mesa dan Kaka Palli merupakan dua kelompok tani yang berada di Kelurahan Kolhua, Kota Kupang yang melakukan usaha budidaya tanaman (padi, jagung, dan sayuran) secara konvensional namun menghadapi kendala berupa penyerapan IPTEKS sangat terbatas sehingga berdampak pada pengelolaan lahan yang belum optimal, petani hanya mengandalkan pupuk kimia, dan belum adanya pengelolaan bahan organik khususnya limbah pertanian secara baik. Tindakan tersebut berdampak pada penurunan kesuburan tanah dan produktivitas lahan yang akhirnya mempengaruhi produksi tanaman. Target kegiatan ini adalah anggota kelompok memiliki kemampuan dan terampil dalam mengelola limbah pertanian menjadi pupuk organik yang didukung dengan tersedianya sarana dan prasarana yang memadai sehingga petani dapat memanfaatkan limbah pertanian dengan menggunakan teknologi tepat guna yang pada akhirnya akan meningkatkan produksi pertanian dan kesejahteraannya. Berkaitan dengan hal tersebut, maka petani perlu mendapat pembelajaran dengan materi yang berkaitan dengan permasalahan yang dihadapi. Pembelajaran disampaikan dengan metode ceramah dan diskusi, demonstrasi, praktik, rancang bangun, demplot, dan pendampingan. Hasil dari kegiatan ini adalah Pelaksanaan kegiatan IbM di Kelompok Tani Dael Mesa dan Kaka Palli Kelurahan Kolhua mendapat respon positif dari anggota kelompok tani, hal ini nyata ditampilkan dari antusiasme anggota kelompok tani mengikuti rangkaian kegiatan IbM dari awal hingga akhir, selanjutnya secara mandiri menerapkan IPTEKS yang diberikan dalam budidaya tanaman dan pembuatan pupuk organik. Bokashi yang dibuat mengandung kadar C-organik = 16,40\%; $\mathrm{N}=2,02 \% ; \mathrm{P}=1,11 \%$; $\mathrm{K}=1,80 \%$; dan $\mathrm{pH}=$ 7.88. Hal ini menunjukkan bahwa bokashi telah memenuhi persyaratan teknis minimal pupuk organik padat yang ditetapkan dalam Peraturan Menteri Pertanian No. 70/SR.140/10/2011 sehingga layak dijadikan sebagai pupuk.
\end{abstract}

Keywords- Bokashi, Limbah, POC, Sayuran

\section{PENDAHULUAN}

Kolhua sebagai salah satu kelurahan terluar wilayah Kota Kupang (NTT) memiliki masyarakat dengan beragam pekerjaan, seperti: petani padi dan hortikultura (sayuran). Para petani menggabungkan diri dalam kelompok tani, diantaranya Kelompok Tani Dael Mesa dan Kaka Palli yang dibentuk tahun 2011. Luasan lahan/sawah yang dimiliki anggota bervariasi antara 10-50 are. Anggota juga memiliki beberapa jenis ternak, yaitu: sapi, kambing, babi, dan ayam kampung dalam jumlah terbatas. Anggota tani juga memiliki lahan mamar yang berisi aneka ragam pohon, seperti: pisang, kelapa, lontar, pinang, dll.

Kelompok Tani Dael Mesa dan Kaka Palli mengalami kendala dalam penyebaran IPTEKS, sehingga budidaya tanaman disesuaikan dengan kebiasaan, keterbatasan pengetahuan dan teknologi, serta dana yang dimiliki. Akibat lainnya, lahan yang diusahakan tidak 
maksimal, produksi tanaman rendah sehingga bersifat subsistem.

Hasil wawancara dengan salah seorang anggota Kelompok Tani Dael Mesa (2015) diperoleh informasi bahwa tanaman sawi dan kangkung selain untuk pemenuhan gizi keluarga, kedua jenis sayuran ini ditanam dengan prioritas untuk dijual dan uang hasil penjualannya dimanfaatkan untuk biaya hidup, pendidikan anak, dan sebagai modal bertanam dan beternak. Sawi dan kangkung dijual seharga Rp. 500,00 - 1.000,00 per ikat atau dapat pula dijual secara borongan dengan harga per bedengan ukuran $2 \times 1$ meter berkisar antara Rp. 15.000,00 - 30.000,00. Penentuan harga jual disesuaikan dengan kondisi/musim.

Tanaman kelapa dan pisang selain di lahan mamar, juga ditanam di sekitar pekarangan dan lahan sawah. Buah kelapa dimanfaatkan sebagai penghilang dahaga dan bahan untuk pembuatan minyak kelapa. Buah pisang yang dipanen, dijual seharga Rp. 5.000,00 $10.000,00$ per sisir. Limbah pohon pisang dijadikan sebagai pakan.

Usaha budidaya tanaman selalu menggunakan produk kimia (pupuk dan pestisida kimia) ditambah dengan perlakuan tanah dan tanaman yang kurang ramah lingkungan bahkan cenderung merusak kesuburan tanah dalam jangka panjang. Hal ini terlihat dari tindakan pembakaran jeramilimbah pertanian di lahan, tidak adanya penggunaan bahan organik (pupuk organik) dalam usaha taninya, dan tidak dilakukannya penanganan atau daur ulang limbah pertanian. Tindakan tersebut dikarenakan petani belum mengetahui bagaimana memanfaatkan limbah pertanian untuk mendukung kegiatan budidaya tanamannya.

Penggunaan pupuk organik untuk pertanaman padi tidak dilakukan, hal ini disebabkan karena kurangnya pengetahuan petani terhadap peranan bahan organik bagi tanah dan tanaman serta ketidaktahuan petani terhadap cara, teknologi pembuatan dan aplikasi pupuk organik dalam budidaya tanamannya. Petani hanya memanfaatkan kotoran hewan yang telah kering untuk tanaman sayuran dengan pemberian seadanya sebagai campuran media tanam. Petani membakar jerami padi di lahan persawahannya dengan harapan dapat menyuburkan tanah sehingga tanaman sayuran yang ditanam setelah padi dipanen dapat memperoleh sumbangan hara dari abu hasil bakaran tersebut. Limbah berupa sekam padi umumnya dibuang, hanya sebagian kecil yang dimanfaatkan untuk pakan ternak babi, yaitu sekam yang tidak mengapung saat dilakukan perendaman dengan air. Dedak padi, limbah sayuran dan jagung dijadikan sebagai pakan ternak.

Potensi dan kendala yang dihadapi kelompok tani di kelurahan Kolhua memungkinkan dilakukannya suatu upaya untuk mengelola limbah pertanian dan sumber daya alam yang ada untuk dijadikan produk (pupuk organik) yang dapat mendukung kegiatan budidaya padi dan sayuran (hortikultura) yang dilakukan.

\section{TARGET DAN LUARAN YANG DICAPAI}

Target luaran yang diharapkan dalam kegiatan IbM ini, adalah: dihasilkannya produk pupuk organik padat (bokashi) dan Cair (Sumber N, P, dan K) dari bahan lokal yang ada selanjutnya produk tersebut diaplikasikan ke kegiatan budidaya padi dan hortikultura yang diusahakan dan jika berlebih dapat dijual untuk menambah pendapatan petani. Untuk memudahkan petani membuat pupuk maka dibangun fasilitas berupa rumah pupuk dan komposter untuk POC. Selain itu, juga dihasilkan paket budidaya tanaman sayuran secara organik.

\section{METODE PELAKSANAAN}

Metode pelaksanaan yang digunakan, yaitu:

1.Penyuluhan/penyadaran, materi yang disampaikan berupa pengelolaan limbah pertanian menjadi pupuk organik padat maupun cair, budidaya tanaman sayuran (sawi dan kangkung); padi; dan jagung secara organik, aplikasi pupuk organik ke 
2.tanaman budidaya, pemasaran produk pertanian berorientasi bisnis dan analisis usaha tani sederhana.

3.Demonstrasi/praktik, meliputi: pembuatan bokashi, dan POC sumber N, P, dan K; Aplikasi pupuk organik (bokashi) sebagai pupuk dasar pada budidaya tanaman (padi, jagung, dan sayuran) serta POC sumber N, P, dan $\mathrm{K}$ sebagai pupuk susulan dalam budidaya sayuran; budidaya padi dan sayuran; serta Menghitung Analisis ekonomi sederhana (analisis usaha tani).

4. Rancang bangun, membangun rumah pupuk organik padat permanen dan beratap dengan ukuran 2 × 2,5 $\times 1$ meter.

5. Model budidaya sayuran (sawi dan kangkung). Budidaya sayuran secara konvensional dan organik dengan memanfaatkan sumber daya yang dimiliki kelompok tani.

6. Pendampingan, dimaksudkan untuk membantu, membimbing, dan menilai tingkat penyerapan dan perkembangan peserta kegiatan pengabdian dalam menerapkan hasil pelatihan.

\section{HASIL DAN PEMBAHASAN}

Kegiatan IbM Kelompok Tani Kelurahan Kolhua dilaksanakan dengan difokuskan pada permasalahan yang dihadapi kelompok tani, melalui kegiatan berikut:

\section{A. Koordinasi Kegiatan}

Tim pelaksana IbM setelah mendapat persetujuan pendanaan maka dilakukan koordinasi kegiatan dengan mitra (kelompok tani). Koordinasi ini dimaksudkan untuk memperoleh kesepakatan bersama mengenai kegiatan yang akan dilaksanakan, jadwal, dan bentuk serta peran kelompok tani dan tim pelaksana dalam kegiatan ini.

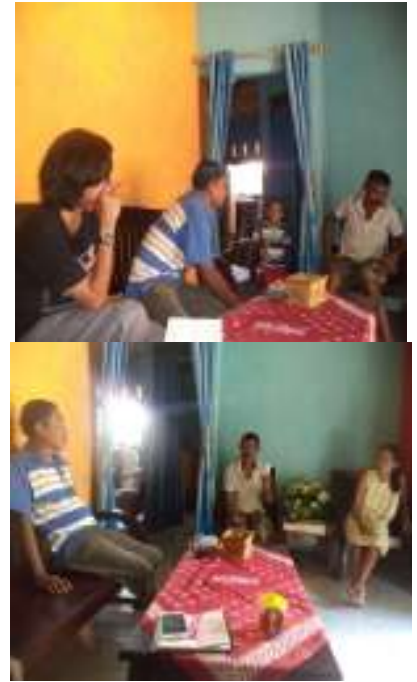

Gambar 1. Koordinasi Kegiatan (Tim dan Ketua Kelompok Tani)

\section{B. Sosialisasi dan Penyuluhan}

Kegiatan sosialisasi dimaksudkan agar anggota kelompok tani mengetahui maksud dan tujuan IbM ini dilaksanakan serta ikut serta dalam pelaksanaan kegiatan yang dimaksud. Kegiatan penyuluhan dilakukan dengan cara penyampaian materi oleh tim pelaksana IbM dan nara sumber, yang terdiri atas: Nova D. Lussy, SP., M.Sc., Micha S. Ratu Rihi, SP., M.Si., Ir. Eko H. A. Juwaningsih, M.Si., dan Chris N. Namah, SE., M.Sc.

Materi penyuluhan yang disampaikan, yaitu: Budidaya Padi secara Organik; Budidaya Jagung secara Organik; Budidaya Kangkung Darat dan Sawi secara Organik; bokashi dan Aplikasinya; Pupuk Organik Cair Sumber Nitrogen; POC sumber Kalium; dan POC sumber Fosfor, serta analisis usaha tani sederhana. Materi tentang budidaya tanaman lebih difokuskan pada budidaya tanaman secara organik. Selain menyampaikan materi, tim dan nara sumber juga memberikan kesempatan ke anggota kelompok untuk menyampaikan permasalahan atau kendala yang dihadapi dalam budidaya tanaman yang dilakukan selama ini. 


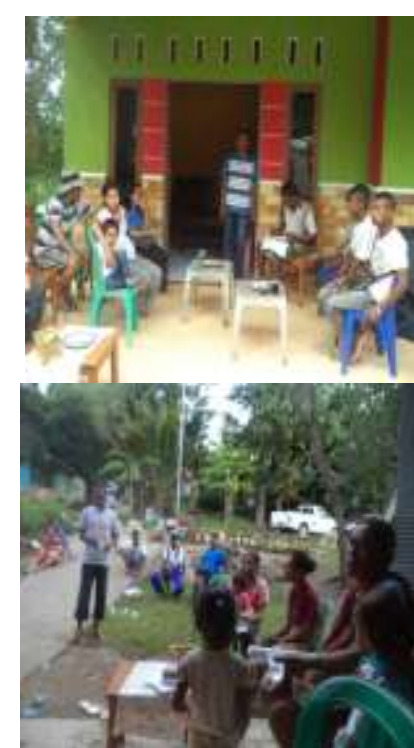

Gambar 2. Kegiatan Penyuluhan

\section{Praktik}

Praktik yang dilakukan, yaitu: pembuatan bokashi; POC sumber N; P; dan K; serta pestisida nabati dan perangkap hama. Kegiatan praktik dilakukan bersama dengan masyarakat yaitu seluruh peserta punyuluhan. Bokashi berbahan dasar kotoran sapi, sekam, daun legum, dengan EM4, sedangkan untuk POC, bahan bakunya berupa: kotoran hewan dan daun legum untuk POC sumber N; batang pisang yang telah dicincang sebagai sumber $\mathrm{P}$; dan sabut kelapa yang dicincang halus untuk POC sumber K.

Pembuatan pestisida nabati dibuat dari beberapa jenis bahan, yaitu: pestisida dari kunyit, tembakau, daun sirsak, daun nimbah, dan daun gamal. Perangkap hama yang dibuat yaitu: perangkap warna dan perangkap lalat buah.

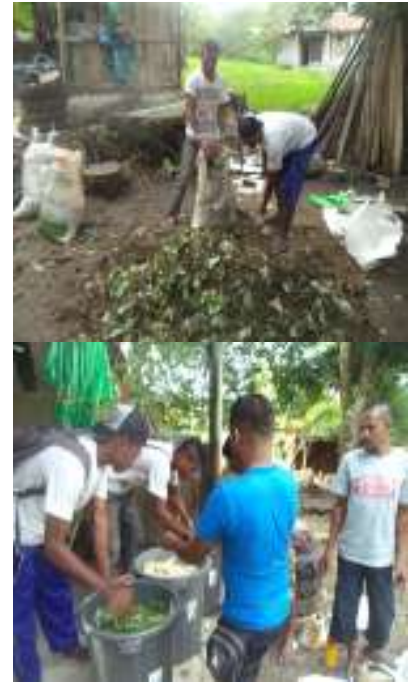

Gambar 3. Praktik Bokashi dan POC

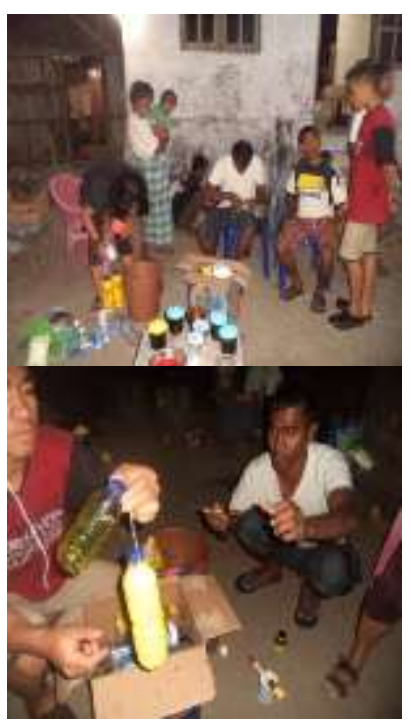

Gambar 4. Praktik Perangkap Warna dan Lalat Buah

\section{Demplot}

Demplot dikhususkan untuk budidaya sayuran. Jenis sayuran disesuaikan dengan yang biasa dibudidayakan petani, yaitu: sawi dan kangkung. Kegiatan demplot diawali pesemaian benih sawi, dan dilanjutkan dengan penanaman. Ada dua model budidaya sawi, yaitu: budidaya tanaman disesuaikan dengan kebiasaan petani dan budidaya secara organik dengan menggunakan bokashi dan POC hasil kegiatan
IbM. 
Aplikasi pupuk organik, yaitu: bokashi 20 ton/ha diberikan sebelum tanam setelah olah tanah dengan cara disebar dan dibenam ke seluruh bedengan, sedangkan POC sumber $\mathrm{N}$ diberikan sebagai pupuk susulan dengan cara satu gelas air mineral (200 - $250 \mathrm{ml}$ ) dilarutkan dalam satu ember air (setara 10 liter) dan disiram ke daerah perakaran tanaman sebanyak satu gelas air mineral dengan interval dua hari sekali. Pemberian POC dihentikan seminggu sebelum tanaman sawi dipanen.

Sawi yang dipanen dikonsumsi secara bersama oleh anggota kelompok. Informasi yang disampaikan petani bahwa tanaman sawi yang ditanam dengan sistem budidaya organik setelah dikonsumsi dinilai rasanya lebih enak dan manis dibandingkan dengan sawi hasil budidaya konvensional yang biasa dilakukan anggota. Selanjutnya kegiatan budidaya sawi dan kangkung dilanjutkan secara mandiri oleh petani di lahan yang dimiliki dengan luasan areal budidaya disesuaikan dengan ketersediaan air yang ada.

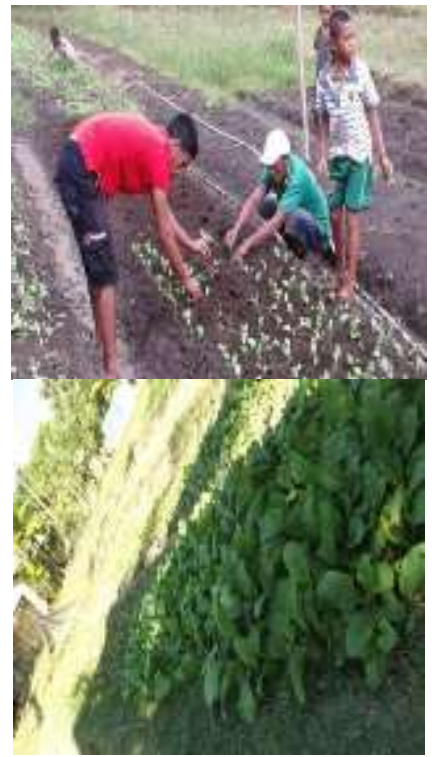

Gambar 5. Demplot Budidaya Sawi

\section{E. Pembangunan Rumah Pupuk Organik}

Pembangunan rumah pupuk organik dimaksudkan untuk memudahkan dalam pembuatan pupuk khususnya bokashi sehingga mudah untuk mengontrol dan memanfaatkannya. Rumah pupuk yang dibangun berupa rumah permanen berlantai semen dan beratap seng berisi dua ruang atau bak dengan ukuran $2 \times 1,5 \mathrm{x}$ 1 meter.

Bokashi yang dibuat kemudian dianalisis beberapa sifat kimianya dan diperoleh kadar C-organik $=16,40 \% ; \mathrm{N}=2,02 \% ; \mathrm{P}=$ $1,11 \% ; \mathrm{K}=1,80 \%$; dan $\mathrm{pH}=7.88$. Hasil analisis pupuk menunjukkan bahwa bokashi yang diproduksi secara umum telah memenuhi persyaratan teknis minimal pupuk organik padat yang dikeluarkan oleh Peraturan Menteri Pertanian No. 70/Permentan/SR. 140/10/2011. Hal ini berarti bahwa bokashi layak dijadikan sebagai pupuk dalam budidaya tanaman bahkan dapat dikomersilkan (dijual).

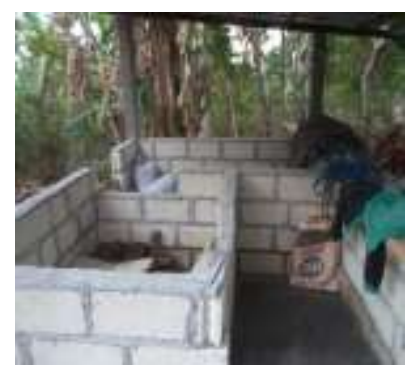

Gambar 6. Rumah Pupuk Organik

Pembuatan bokashi selain digunakan dalam kegiatan budidaya juga dapat dijual ke pasaran. Secara ekonomi, jika pupuk tersebut dijual akan memperoleh pendapatan tambahan bagi petani. Hasil perhitungan ekonomi untuk usaha bokashi didapatkan nilai $\mathrm{R} / \mathrm{C}=1,46$. Hal ini menunjukkan bahwa usaha bokashi layak untuk dikembangkan dan dapat memberikan keuntungan yang cukup besar. Jika petani mau mengusahakan bokashi untuk dikomersilkan selain dimanfaatkan dalam budidaya tanaman maka akan memberikan tambahan pendapatan di luar kegiatan budidaya sehingga penghasilan meningkat yang akhirnya akan dapat meningkatkan kesejahteraan petani/anggota tani. 


\section{F. Pendampingan}

Pendampingan dimaksudkan untuk mengetahui penerapan Ipteks oleh petani. Pelaksanaan kegiatan IbM mendapat respon positif dari kelompok tani kelurahan Kolhua khususnya Kelompok Tani Dael Mesa dan Kaka Palli. Hal ini terlihat dari kehadiran dan keaktifan anggota kelompok tani dalam mengikuti rangkaian kegiatan dari awal hingga akhir pelaksanaan. Selain itu respon positif juga ditunjukkan dengan kesediaan untuk memberikan waktu, tempat, lahan untuk demplot dan pembangunan rumah pupuk, serta alat dan bahan lokal yang diperlukan untuk mendukung terlaksananya kegiatan IbM dimaksud. Anggota kelompok tani antusias dalam menerima dan menerapkan teknologi yang diberikan, khususnya pengelolaan limbah pertanian menjadi pupuk organik padat dan cair yang dinilai merupakan hal baru bagi mereka.

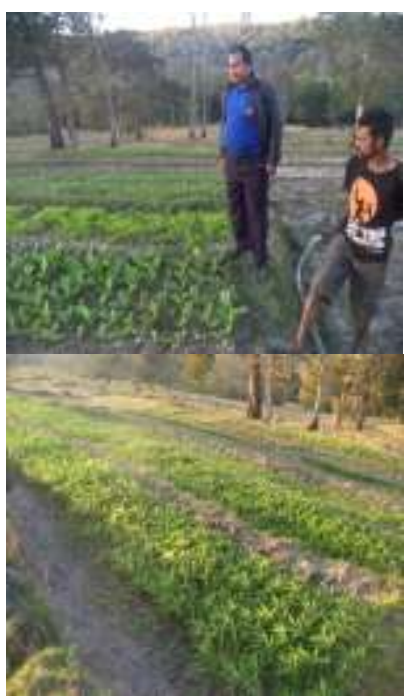

Gambar 7. Budidaya Sawi dan Kangkung oleh Petani Secara Mandiri

\section{KESIMPULAN}

1. Tahapan pelaksanaan kegiatan IbM di Kelompok Tani Kelurahan Kolhua, terdiri atas: koordinasi kegiatan, Sosialisasi, Penyuluhan, Praktik, Demplot, Pembangunan rumah pupuk, dan
Pendampingan kegiatan telah dilaksanakan sesuai rencana.

2. Pelaksanaan kegiatan IbM di Kelompok Tani Dael Mesa dan Kaka Palli Kelurahan Kolhua mendapat respon positif dari anggota kelompok tani, hal ini nyata ditampilkan dari antusiasme anggota kelompok tani mengikuti rangkaian kegiatan IbM dari awal hingga akhir, selanjutnya secara mandiri menerapkan IPTEKS yang diberikan dalam budidaya tanaman dan pembuatan pupuk organik.

3. Hasil analisis C-Organik; N; P2O5; K2O; dan pH bokashi menunjukkan bahwa bokashi dibuat dinilai telah memenuhi persyaratan teknis minimal pupuk organik padat yang ditetapkan oleh Peraturan Menteri Pertanian No. 70/SR.140/10/2011 sehingga layak dijadikan sebagai pupuk karena dan dari hasil analisis usaha diperoleh nilai $\mathrm{R} / \mathrm{C}=1,46$ sehingga secara ekonomis, bokashi layak untuk diusahakan.

\section{UCAPAN TERIMA KASIH}

Direktorat Riset dan Pengabdian Kepada Masyarakat. Kementerian Riset, Teknologi, dan Pendidikan Tinggi yang telah mendanai kegiatan ini.

\section{DAFTAR PUSTAKA}

Setyohadi, D.P.S., Utami, M.M.D., Kurnianto, M.F. and Hariono, B., 2018, January. Capital Strategy in Diversification Farming Efforts Using SWOT Analysis. In Journal of Physics: Conference Series (Vol. 953, No. 1, p. 012121). IOP Publishing.

Hadisuwito, S., 2007. Membuat pupuk kompos cair. AgroMedia.

Indriani, Y. H. 2004. Membuat Kompos Secara Kilat. Penebar Swadaya.

Menteri Pertanian, 2011. Peraturan Menteri Pertanian Nomor: 70/SR.140/10/2011 tentang Pupuk Organik, Pupuk Hayati, dan Pembenah Tanah.

Musnawar, E. I., 2007. Pupuk Organik. Penebar Swadaya. 